\title{
Educational games in physical education to increase self- confidenceChildren with Special Needs in Padang Special School Perwari
}

\author{
Tri Rafi Harma ${ }^{1}$, Eddy Marheni ${ }^{2}$, Eko Purnomo ${ }^{3}$ \\ 1Universitas Negeri Padang, Padang- Indonesia, $\square$ trirafiharma310398@gmail.com \\ ${ }^{2}$ Universitas Negeri Padang, Padang- Indonesia, \eddymarheni@fik.unp.ac.id \\ 3Universitas Negeri Padang, Padang- Indonesia, \ekopurnomo@fik.unp.ac.id
}

\begin{abstract}
This research is based on the problem of trust in children with special needs. Learning development methods are not only in the classroom, can also be done outside the classroom. The purpose of this study is to provide solutions in solving problems of more effective learning planning systems in educational games in the field. This research was conducted on August 3 - September 28, 2018 at the Perwari Padang, Perwari. The focus of the research is on game modification learning that has been conducted at Padang Perwari school. This type of research is qualitative research with the observation method, the education educative game program, and documentation. The main object in this study is students with special needs in Padang Perwari. The results of research on good social interaction, the emergence of cooperation in completing a game, and the growth of confidence in interacting with friends in completing physical activities.
\end{abstract}

Keywords: Self-confidence, Special Schools, Children with special needs.

How to Cite: Tri Rafi Harma, Eddy Marheni, Eko Purnomo.(2018). Educational games in physical education to increase self-confidencechildren with special needs in padang special school perwari. International Conferences ofMental Health, Neuroscience andCyberpsichology. Padang:Fakultas Ilmu Pendidikan, Universitas Negeri Padang Publishing.

\section{Introduction}

Education is learning knowledge, skill, and the habits of a group of people who are passed down from generation to generation through teaching, training, or research. Education often occurs under the guidance of others, but also allows self-taught. Education is a conscious effort to influence students to be able to develop and actualize the potential potential possessed in order to be able to 
live life as well as possible. The potential that exists within each student is positive or in the form of education (Utama, 2011). In the development of this process can take place in a family environment, school, and society. Understanding education in the national education system is an attempt to prepare students through the teaching and learning process (Prastowo dan Syam, 2014). This means that education can be done without knowing the age limit, space and time. In the 1945 Constitution article 31 paragraph 1 which states "that every citizen has the right to get education" (utari dan indahwati, 2015). This verse sounds in line with the concept of education for all (education for all) which is affirmed in the universal declaration of Human Rights.

Character is a behavior that is shown by someone in daily life who has a tendency towards positive or negative. Then it develops the notion of character which is defined as a special sign or pattern of behavior (Bohlin et.al, 2001). The term character comes from the Greek "charassein" which means to carve. (Elmubarok, 2008). Mention that character building is the process of carving or carving souls in such a way, so it is unique, interesting, and different or can be distinguished from others, like a letter in the alphabeta that is never the same as one another.so people with character can be distinguished from one another, a person with a commendable character can be distinguished from the others (Lickona, 1991:50). Forming a likened character is like carving on a gemstone or a hard iron surface. Character is a special personality that is the driving force and driving force, and what distinguishes it from other individuals (Hidayatullah, 2010). This character education aims to be able to shape the character / personality of the nation's children in accordance with the Law Number 14 of 2005 concerning the National Education System (sisdiknas) article 3 which is faithful and devoted to the Almighty God, noble, competent, creative, independent and become a democratic citizen and responsibility. (Lickona, 1991) states that character education is a deliberate effort to help someone so that he can understand, pay attention, and carry out core ethical values. Characters are shaped by good habits and are also shaped by the environment and education that researchers get.

Self-confidenceis a positive attitude of an individual who convinces himself to complete something he will do and develop positive values both for himself and for the environment / situation he faces. (Horn, 2008)defines confidence as a belief that someone has internal resources,especially ability.Selfconfidence is a personality trait that implies the belief in one's own abilities, so that individuals are not easily influenced by others (Lautser, 2003).To achieve success, that is, confidence is rooted in faith and hope. Self-confidence is an absolute personality aspect that every individual must possess because it relates to confidence "I can". Whereas according to (Al-uqshari, 2005). Confidence in a form of strong belief in the soul, understanding with the soul, danability to master the soul.

The child with special neededare children with special characteristics that are different from children in general without always showing mental disability,emotional or physical.Based on this understanding, children who are categorized as having physical aspects include abnormalities in the sense of sight (blind),hearing sensory abnormalities (deaf), speech impairment, (speech impaired) and limb function abnormalities (disabled) (Abdullah, 2013). The term "special needs" is explicitly aimed at children who are considered to have abnormalities / deviations from the average condition of normal children generally, in physical terms, mental and social behavior characteristics (Efendi, 2006). Children with special needs include children with disabilities namely students who experience significant deviations or differences from the condition of people in general (average),so students need special educational services so that students can develop their potential optimally.These deviations can occur in the physical, mental aspects, social and or emotional (Maftuhatin, 2014).

An extraordinary school is one of the educational institutions with the aim to fulfill national education goals as well as to explore the abilities of students with optimal special needs (Irsyadi dan Nugroho, 2015).the government affirms that every citizen has the right to education. Di Indonesia pendidikan bagi anak yang memiliki keterbatasan telah diamanatkan dalamri Law No. 20 of 2003 
concerning the Implementation of Special Education for Students.Special education is education for students who have difficulty in following the learning process due to physical abnormalities, emotional, mentally, social, and/or has special intelligence and talent potential (pasal 127).

The function of the game in improving child growth and development is very good.Play has an important role in human life that can be seen from the psychological aspect, physical,and social.through play there will be positive changes in physical matters, social, mentally, and moral (Sukintaka, 1998). Some components of the psychological aspects will develop through playamong others in terms of intelligence, motivation, emotion, mentally, confidence, interest, will, worry, aggressiveness, attention, concentration, etc (Utama, 2011). Physical aspects will also develop well through playing activities, includes physical growth and development, physical fitness, physical health, basic motion capability,existing physical elements.Even social aspects will develop well through this playing activity between in terms of cooperation, communication, mutual trust, respect, community, tolerance, togetherness and so on.

Children who are confident will have characteristics, among others:more independent, not too dependent on people, able to assume the responsibility given, can respect yourself and his own business, not easily experience frustration, able to accept new challenges or tasks, have more vibrant emotions but remain stable, easy to communicate and help others (Adywibowo, 2010). According to Eko Sugiarto (2009), the characteristics of a shy child (inferiority)what researchers can observe is: often avoid eye contact (looking down / throwing the other direction), often go berserk to release anxiety, not much to say (often answer enough when asked,as: "yes" or "no",even just nodding or shaking his head), do not want to follow activities in class or outside class (passive), do not want to ask for help or ask people who are not well known, experience stage fright at certain times, for example when asked to come to the front of the class, it's difficult to blend in with the new environment / situation (it takes a long time to adjust).

Based on the results of observations made at the extraordinary school of Perwari Padangresearchers identified the difficulty of students doing a physical movement that resulted in a lack of confidence in children with special needs. Things that make researchers interested in doing research on Educational Games in Physical Education to Increase Self-Confidence of Children with Special Needs in Padang Special School Perwari.The aim of the researcher is to find out the level of confidence that children with special needs have in Padang Perwari Special School.

\section{Methodology}

The type of research used in this study is qualitative research, with data collection methods using interviews and observations. This research was conducted on 2 August - 29 September 2018 at Padang Perwari Special School, Sumatera Barat.In addition the application process, researchers lined up children with special needs in advance to give direction regarding the implementation of the game to be carried out.After the children line up neatly, the researcher exemplifies or demonstrates the game that the researcher has made, by passing various obstacles from star to finish well,After giving directions about the correct game, the researcher gives the opportunity for the child to play games alternately with his friends.Subjects in this study amounted to 20 students who were children with special needs in the extraordinary school Perwari Padang. The data collection techniques and tools use observation, interview and documentation methods.Data analysis techniques in this study are more of a description of the results of observations,interviews and documentation. Data that has been obtained qualitatively and described in descriptive form (Patton, 2001:103). The data analysis technique used in this study is to use steps like those proposed by (Bungin, 2003:70). Namely as follows:

1. Data collection

2. Data reduction 


\section{Data display}

4. Conclution drawing and verification

Research Instruments:

The research instrument is to use educational game methods in the form of physical education.The form of the game is to bring and then enter the ball through the obstacle obstacles that have been prepared.Materials or tools to make these obstacles are:

1. Rainbow carton.

2. Used cardboard.

3. Used shoelaces.

4. 1 piece of used shoe box.

5. Small plastic balls with 3 kinds of colors totaling 20 pieces.

6. 10 pieces of $600 \mathrm{ml}$ mineral plastic bottles and 5 pieces of $1000 \mathrm{ml} / 1$ liter plastic bottles, used bottles are used mineral plastic bottles

7. Ravia rope.

8. One piece of water paralon 1.5 meter long, the water used is paralon of used water.

9. Bench that has the same size 2 pieces.

10. 1 piece of used ceramics

11. And 3 pieces of plastic waste baskets are cleaned, this basket is adjusted to 3 different colors of the ball.

Bring together ingredients:

1. Make a necklace from rainbow cardboard and used cardboard with a star shape, then glue it with a used shoe string to resemble a star necklace

2. Enter the 20 colored balls into the shoe box.

3. Fill all mineral bottles with water

4. Prepare $10600 \mathrm{ml}$ bottles, then cut a 1 meter raffia rope with both ends of the rope tied to the mineral bottle head, one end of the rope uses one bottle of mineral,then in one meter the rope consists of 2 bottles of mineral.

5. Place the paralon above the back of the chair.

Arrange the game:

1. Place the box containing the ball near the star line

2. Arrange the $600 \mathrm{ml}$ bottle that has been tied together with a distance of 1 meter each,the rope must be tense to be jumped.

3. Arrange the $1000 \mathrm{ml} / 1$ liter mineral bottle straight towards the finish line,to be able to do a zikzak move.

4. After that, place the chair with paralon above the backrest, resembles a cave to be passed below.

5. Put the used ceramic as a support board, for the place to throw the ball into the basket.

6. Arrange the basket to widen at the same distance.

Examples of game forms:

1. Use a star necklace.

2. Take the ball in the box.

3. Jump over the rope that has been tied to the mineral bottle.

4. Move the zik-zak through plastic bottles.

5. Pass the chair and paralon underneath.

6. Stand with both feet on the pedestal ceramic.

7. Insert the ball into the basket, the color of the ball that is inserted must match the color of the basket.

8. Run towards the star line.

9. Give a star necklace to a friend who will do the next.

10. That's how it goes until all students finish doing it. 
Picture 1. Desain Educational Games.
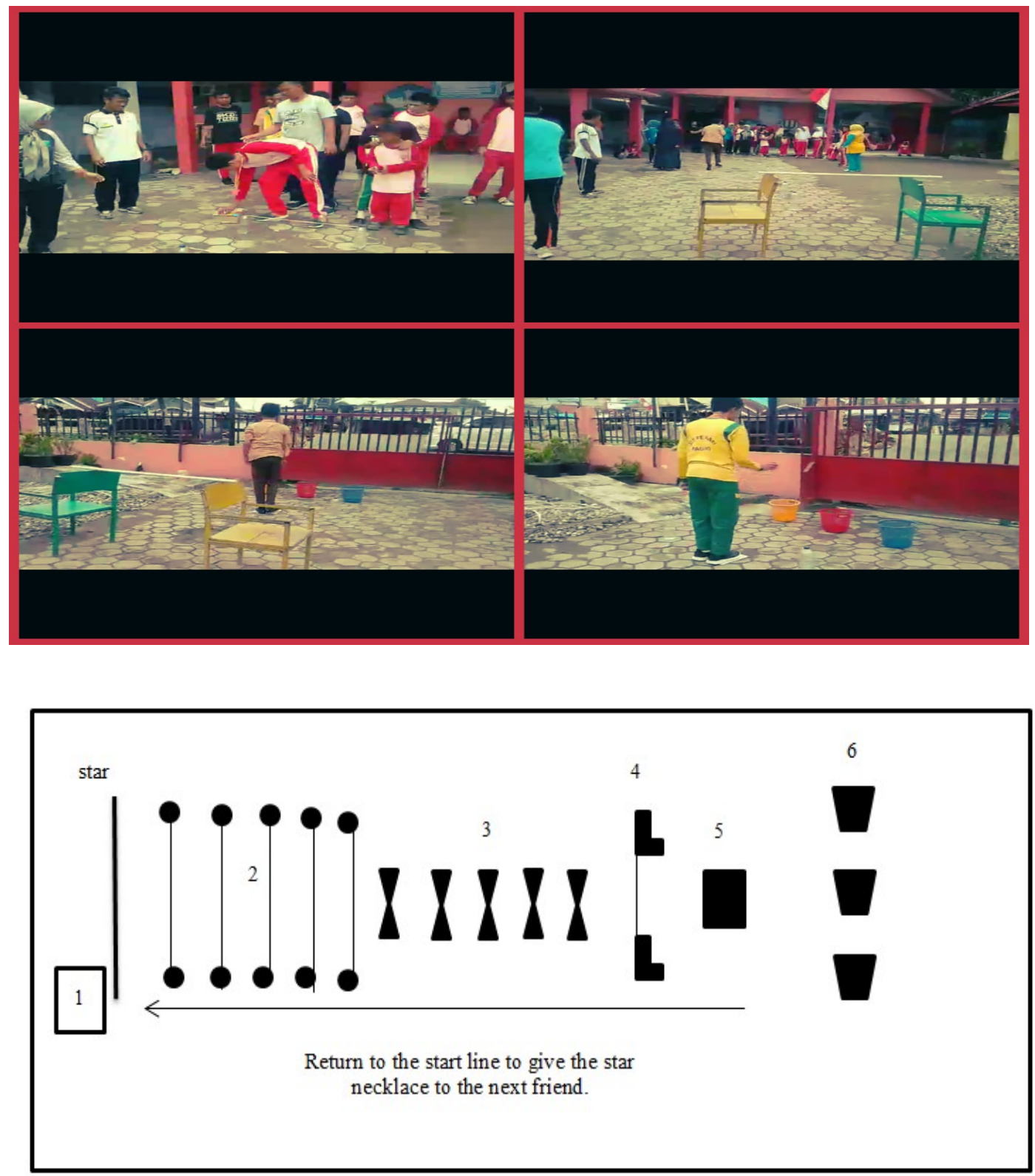

$1=$ box containing a ball

$2=$ mineral bottle tied with rope

$4=$ chair and paralon

$3=$ mineral bottle $1 \mathrm{~L}$ replacement kun

$$
\begin{aligned}
& 4=\text { chair and paralon } \\
& 5=\text { ceramic } / \text { board support } \\
& 6=\text { basket }
\end{aligned}
$$

\section{Results and Discussion}

From the results of research conducted by researchers found a problem of confidence when playing a game, the difficulty of students in carrying out physical activities creates problems in students' emotions which results in the emergence of a lack of confidence in children. Physical inability can cause striking inferior feelings so that self-confidence cannot be realized properly (Lauster, 2005). Physical aspect is a potential that develops and must be developed by individuals (Somantri, 2006). Motor function in human life is very important, especially if someone wants to make contact with the environment, both the social environment and the surrounding natural environment (Lathifah, 2015). During the game there are some children who have very little 
confidence, at that time the teacher at the school helped support or convince the child to do it. The role of the people around them is very important to provide motivation and assistance to solve problems experienced by children (Lathifah, 2015). Then the role of people in the school environment such as friends and teachers, and parties from other schools (Sokolova, 2008). Providing motivation and support makes shy children who ultimately want to do it, even though when playing a game there is a problem with the gross motor, but thanks to the motivation and support of the environment that made him believe and believe in completing or completing the game, this proves that playing is not only a physical aspect that develops but also social, This agreed with Sukintaka (1998) which states that through playing there will be positive changes in physical matters,social, mental, and moral.

Researchers also concluded that through playing children can channel or release energy and emotions that have been latent which makes turmoil in students' self-confidence, when playing children various kinds of happiness like shouting, running around, circling and others. Hurlock (1978) stated about the influence of playing in the world of children,that play has to do with child development,these influences include:the urge to communicate, channeling to pent-up emotional energy, Learning Resources, self-insight development, community learning, moral standards.

Encouragement to Communicate

Through play activity encourages children to learn to build communication between children so that a form of activity occurs (Moeslichatoen, 1999:32). Communication is important for science (Noviyanti, 2011). In the game made by researchers there is an element of cooperation, giving a necklace to a friend supports communication in collaboration while playing.

\section{Distribution for Hidden Emotional Energy}

Playing will satisfy the demands of motoric development needs, cognitive / creativity, language, social, values and attitudes of life (Moeslichatoen, 1999:32). Playing is a medium for channeling potential tensions or energy caused by environmental restrictions on students' life behavior (Hurlock, 1978:323).In the game given by child researchers can realize the energy and emotion that students have been inclined to because it is difficult to reach a physical activity,by modifying a game that is easy to achieve and that he never met made the students happy and released the elements of energy and emotion that were controlled in the game media that the researchers gave.

\section{Learning Resources}

Playing provides a wide opportunity for children to learn various fields that are not obtained through studying at school, family and community (Moeslichatoen, 1999:32). Playing is a learning experience that is very useful for children, some of the benefits of playing include (Maykes, 2001:3045); For the development of physical aspects, For the development of gross motor and fine motor aspects, For the development of social aspects, For the development of emotional or personality aspects, For the development of cognitive aspects, To sharpen sensing sharpness, To develop sports and dance skills.From the game that the researcher gave researchers, it was concluded that through children's play learning to interact, get to know an object, solve a moving circuit, and learning to socialize in communicating.

\section{Development of Self-Insight}

Playing is a mirror in children's lives.Through play the child is able to see himself because there are benchmarks or comparisons that are friends or opponents playing, so students know their 
strengths and weaknesses in various fields such as physical, psikis, dan social (Moeslichatoen, 1999:32). The mental values contained in play activities are as follows; (a)children become aware of their rights and learn to respect others, (b)trust each other among playmates, (c)recognize self deficiencies, when compared to others. Added with children also recognizes the strengths of others and controls the emotions of excessive movement (Simatupang, 2005).Through play activities provided by the child researcher will learn in the community by communicating with his friends, with the teacher, and with researchers, learn to respect to take turns waiting to play, learn to obey the rules of the game that the researcher has set in the game,togetherness and cooperation in playing games.

\section{Community Learning}

Playing can also be interpreted as the center of "community" activities for children.In social life there is certainly communication, social relations, value of cooperation, helping each other, there are rules that must be obeyed, there is a common goal to be achieved, mutual respect, mutual trust, ada rasa senang, love, togetherness, harmony, and peace. (Moeslichatoen, 1999:32). The benefits of playing in terms of social aspects will increase the relationship, add familiarity, recreation, so as not to be insulted, dapat berkumpul, prevent riots, in order to avoid drugs, trap a naughty friend (Patmonodewo, 2000:17).Through play activities provided by the child researcher will learn in the community by communicating with his friends, learn to respect to take turns waiting for your turn to play, learn to obey the rules of the game that the researcher has set in the game,togetherness and cooperation in playing games.

\section{Moral Standards}

Playing can also be a moral standard which means that through playing can be seen both the bad attitudes or behavior of children when playing.In children's play activities, they are free to express all their abilities freely in terms of attitude, behavior or speech, so that children who have a habit of behaving well or bad will appear in the play activity (Moeslichatoen, 1999:32).in playing activities in each of the culprit also required to have honesty, get good cooperation, sportive,subject to the rules of the game that have been outlined.With the provisions that must be obeyed in playing activities, then indirectly the regulations carried out in play activities will be embedded in the child (Simatupang, 2005). When the child performs game activities given by the researcher, children apply sportsmanship by alternating regularly, do good cooperation, and follow all the rules of the game that the researcher has submitted, although there are some children who behave poorly, like taking the ball forcibly from another friend, and there are also those who issued words that should not be spoken, so the researcher gives advice and direction to students who carry out the action so that they know that it's wrong and then stop to do it.

In accordance with the results of interviews and observations that the researchers obtained in the field that the students who were in Padang Perwari Special School were initially shy to do the game activities provided by the researchers, after students do and are given support from their environment,make students excited and want to try the game again. The problem of self-confidence in children must be handled or addressed quickly so as not to damage other social aspects that will adversely affect the child's soul. With confidence someone is able to develop the skills they have and children can do what they want well (Lathifa, 2015). Actually humans have their advantages and disadvantages, with the method given, researchers must see the advantages and disadvantages of students in Padang Perwari Special School to conduct an effective learning process so that students are able to capture what the researchers convey.

\section{Conclusions and Recommendations}


From the results and discussion above the researcher concludes that playing is a physical activity that is carried out in earnest and voluntary and fun that is often done by most children.The impact of playing is not only on the physical aspects but also on the social aspects, melalui permainan edukatif dalam pendidikan jasmani yang diberikan peneliti, the child is able to build his confidence in interacting, communicate, cooperation, and children do not know the shortcomings, but also the strengths that exist in children.

\section{References}

Abdullah, N. (2013).Mengenal Anak Berkebutuhan Khusus. Psikologi UNWIDHA Klaten Magistra No. 86 Th. XXV Desember 20131 ISSN 0215-9511.

Adywibowo, I. P. (2010). Memperkuat Kepercayaan Diri Anak melalui Percakapan Referensial. Jurnal Pendidikan Penabur - No.15/Tahun ke-9/Desember 2010. ISSN: 1412-2588

Al-usqhari, Y. (2005). Percaya Diri, Pasti! Diterjemahkan Abdul Hayyie Al-Kattani, Noor Cholis Hamzain. Jakarta: Gema Insani Press

Bohlin, E. K., Deborah F., \& Kevin R. (2001). Building Character inSchool Resource Guide. San Fransisco: Jossey Bass

Bungin, B. (2003). Analisis Data Penelitian Kualitatif. Jakarta: PT Raja Grafindo Persada

Efendi, M. (2006). Pengantar Psikopedagogik Anak Berkelainan, Jakarta, Bumi Aksara

Elmubarok, Z. (2008). Membumikan Pendidikan Nilai. Bandung: Alfabeta

Hidayatullah, F. (2010). Pendidikan Karakter Membangun Peradaban Bangsa. Surakarta: Yuma Pustaka

Horn, T. S. (2008). Advances In Sport Psychologis. USA: Human kinetics.

Irsyadi, F. Y. dan Nugroho, Y. S. (2015). Game Edukasi Pengenalan Anggota Tubuh Dan Pengenalan Angka Untuk Anak Berkebutuhan Khusus (Abk) Tunagrahita Berbasis Kinect. Prosiding SNATIF Ke -2 Tahun 2015 ISBN: 978-602-1180-21-1

Lathifah, I. 2015. Metode Pengembangan Kepercayaan Diri Anak Tuna Daksa Di Sekolah Luar Biasa (Slb) C Kemala Bhayangkari 2 Gresik. Skripsi Fakultas Ushuluddin Universitas Islam Negeri Walisongo. Belum Di Cetak

Lauster, P. 2005. Tes Kepribadian terj. D.H. Gulo, Jakarta: Bumi Aksara

Lautser, P. (2003). Tes kepribadian (alih bahasa: D.H. Gulo). Jakarta: PT. Bumi Aksara

Lickona, T. (1991). Educating for Character: How Our School Can Teach Respect and Responsibility. New York: Bantam Books

Maftuhatin, L. (2014). Evaluasi Pembelajaran Anak Berkebutuhan Khusus (Abk) Di Kelas Inklusif Di Sd Plus Darul Ulum Jombang. Jombang: Universitas Pesantren Tinggi Darul Ulum Jombang 
Maykes, T. (2001). Bermainmainan dan Permainan. Jakarta: Grasindo

Moeslichatoen, (1999). Metode Pengajaran di Taman Kanak-kanak, Jakarta :PT.Rineka Cipta

Noviyanti, M. (2011).Pengaruh Motivasi Dan Keterampilan Berkomunikasi Terhadap Prestasi Belajar Mahasiswa Pada Tutorial Online Berbasis Pendekatan Kontekstual Pada Matakuliah Statistika Pendidikan. FKIP-UT. Volume 12

Patmonodewo. (2000). Pendidikan Anak Prasekolah. Jakarta: Depdikbud dan Penerbit RinekaCipta

Patton, M. Q. (2002). QualitativeResearchand Evaluation Methods (3rded.). Thousand Oaks, CA: Sage Publications, Inc

Prastowo, G. \& Syam, A. R. (2014). Pengaruh Metode Pembelajaran Part Practice Terhadap Hasil Belajar Shooting Bola Basket (Studi Pada Siswa Kelas Xi-Ips Sma Negeri 1 Cerme).Jurnal Pendidikan Olahraga dan Kesehatan Volume 02 Nomor 03 Tahun 2014, 747 - 749 ISSN : 2338-798X

Simatupang, N. (2005). Bermain Sebagai Upaya Dini Menanamkan Aspek Sosial Bagi Siswa Sekolah Dasar. SKRIPSI belum di cetak

Sokolova, I. V, dkk. 2008. Kepribadian Anak. Jogjakarta: Katahati

Somantri, T. S. 2006. Psikologi Anak Luar Biasa. Bandung: Refika Aditama

Sukintaka. (1998). Teori Bermain untuk Pendidkan Jasmani. Yogyakarta: FPOKIKIP

Utama, B. (2011). Pembentukan Karakter Anak Melalui Aktivitas Bermain Dalam Pendidikan Jasmani. Yogyakarta: Universitas Negeri Yogyakarta

Utari, Y. I. \& Indahwati, N. (2015). Upaya Meningkatkan Gerak Dasar Lokomotor Anak Tunagrahita Ringan Melalui Permainan Tradisional (Pada Siswa- Siswi Sekolah DasarLuar Biasa Tunas Mulya Surabaya). Jurnal Pendidikan Olahraga dan Kesehatan Volume 03 Nomor 02 Tahun 2015, 279 -282 ISSN : 2338-798X 